\title{
PENTINGNYA PERSATUAN DAN KESATUAN DALAM MEMBANGUN NKRI
}

\author{
Muhammad Miftachul Mafakhir \\ Institut Ilmu Kesehatan Surya Mitra Husada Indonesia
}

miftachulmuhammad15@gmail.com

\begin{abstract}
ABSTRAK-Dalam membangun persatuan dan kesatuan dalam melindungi Negara republik Indonesia kita harus bisa mewujudkan kebersamaan, saling bahu-membahu,dan hidup rukun merupakan wujud keserasian dan keselarasan dalam masyarakat yang menjadi faktor pendukung untuk mencapai kemajuan dan kejayaan bangsa Indonesia. Apabila seseorang sudah mementingkan kepentingan individu yang tidak memperhatikan kepentingan sosial, maka untuk menuju kemajuan dan kejayaan bangsa Indonesia akan sulit tercapai. Gotong-royong merupakan wujud dari kerukunan hidup masyarakat yang di mana hidup rukun merupakan hidup yang terjauh dari perselisihan atau konflik antar masyarakat.maka dari itu kita harus selalu manjaga persatuan dan kesatuan untuk menjaga Negara kita ini. Apabila kerukunan tersebut tidak ada dalam masyarakat maka gotong-royong ini tidak akan ada dalam masyarakat. Dengan demikian, sifat kebersamaan dan saling bahu-membahu harus tertanamkan pada setiap warga negara Indonesia. Faktor yang terpenting untuk menuju kejayaan dan kemajuan bangsa Indonesia adalah persatuan dan kesatuan semua warga negara Indonesia. Dengan asas kebersamaan, saling bahu-membahu, dan hidup rukun yang dilakukan oleh semua pihak, maka semua permasalahan-permasalahan yang ada dalam Negara ini cepat terselesaikan. iv
\end{abstract}

Latar Belakang Masalah-Bangsa Indonesia memiliki banyak perbedaan.akan tetapi,bangsa Indonesia juga memiliki banyak persamaan.dalam naskah sumpah pemuda kita telah mengikrarkan bahwa kita adalah satu bangsa,bangsa Indonesia.kita mengakui bahwa kita satu tumpah darah,tumpah darah Indonesia.kita juga mengakui bahwa kita menjunjung tinggi bahasa persatuan,yaitu bahasa Indonesia.itulah tiga persamaan yang dimiliki bangsa Indonesia.kita juga memiliki pancasila,undangundang Dasar 1945, dan sang saka merah putih.semua itu adalah lambang pemersatu bangsa.agar persatuan dan kesatuan indonesia terjaga.oleh karena itu,kebersamaan antara sesama bangsa indonesia haruslah tetap di lestarikan.jangan sampai Negara kita mudah diadu domba oleh Negara lain.kita harus bisa saling menghormati satu sama lain, dan jangan sampai masalah kecil di selesaikan dengan kekerasan.karena dengan pertikaian kita mudah diadu domba.sebagai bangsa Negara yang baik kita harus menjaga persatuan dan kesatuan,seperti yang ada pada pancasila sila ketiga,yaitu persatuan indonesia. Rumusan Masalah Apa yang harus di lakukan untuk bisa menjaga persatuan dan kesatuan? Pengaruh budaya luar terhadap Budaya Indonesia 1

Tinjauan Pustaka - 1.Tinjauan historis Pembahasan historis persatuan dan kesatuan Permasalahan Pancasila yang masih terasa mengganjal adalah tentang penghayatan dan pengamalannya saja. Hal ini tampaknya belum terselesaikan oleh berbagai peraturan operasional tentangnya. tampaknya jugabelum 
diikuti upaya penghayatan dan pengamalan Pancasila.Tentu kita Tinjauan historis Pancasila dalam kurun waktu tersebut kiranya cukup untuk memperoleh gambaran yang memadai tentang proses persatuan dan kesatuan menjadi Pancasila otentik. Hal itu perlu dilakukan mengingat bahwa dalam membahas persatuan dan kesatuan kita terikat pada rumusan Pancasila yang otentik dan pola hubungan sila-silanya yang selalu merupakan satu kebulatan yang utuh.bumi indonesia kaya akan hasil alam.semua kekayaan itu haruslah dimanfaatkan sebaik-baiknya untuk kemakmuran rakyat.salah satu caranya adalah dengan menjaga keutuhan indonesia.jika indonesia tidak lagi utuh,maka kekayaan bumi indonesia tidak akan dinikmati oleh seluruh rakyat indonesia.kita tidak boleh membiarkan sekecil apapun Negara republik indonesia lepas.kita juga tidak boleh membiarkan kekayaan indonesia dinikmati oleh sedikit orang saja, maka dari itu kita sebagai warga Negara harus bisa membangun Negara yang bersatu,adil,dan tenteram. 2. tinjauan sosiologis Di tinjau secara sosiologis persatuan dan kesatuan sangatlah penting untuk di laksanakan.karena rasa persatuan dan kesatuan sangatlah pentig untuk membantu dalam meningkatkan rasa persatuan yang ada pada diri masyarakat.rasa persatuan dan kesatuan di antara suku-bangsa di nusantara semakin tebal.puncaknya adalah saat para pemuda dari berbagai penjuru nusantara mengikrakan sumpah pemuda.sejak saat itu, rasa persatuan dan kesatuan bangsa indonesia tidak lagi tergoyahkan. 2

3.Tinjauan yuridis Meskipun nama persatuan dan kesatuan tersebut sesuai dengan posisi Pancasila sebagai sumber tertinggi tertib hukum atau sumber dari segala sumber hukum.dengan demikian,segala hukum di Indonesia harus bersumber pada Pancasila,sehingga dalam konteks sebagai negara yang berdasarkan hukm.negara dan Pemerintah Indonesia tunduk kepada Pancasila sebagai kekuasaan tertinggi.oleh karena itu dapatlah dimengerti bahwa seluruh undang-undang, peraturan-peraturan operasional dan atau hukum lain yang mengikutinya bukan hanya tidak boleh bertentangan dengan Pancasila,seluruh hukum itu merupakan jaminan terhadap penjabaran, pelaksanaan, penerapan Pancasila.Demikianlah tinjauan historis, sosiologis dan yuridis, pelaksanaan dan pengamanannya sebagai dasar negara bersifat imperative memaksa, karena pelanggaran terhadapnya dapt dikenai tindakan berdasarkan hukum positif yang pada dasarnya merupakan jaminan penjabaran, pelaksanaan dan penerapan Pancasila. 3

PEMBAHASAN-Dengan adanya rumusan masalah yang disediakan, maka di uraikan jawaban dari masalah tersebut sebagai berikut 1 . Apa yang harus di lakukan untuk bisa menjaga persatuan dan kesatuan? Negara mengatasi segala paham golongan,etnis,suku,ras,individu, maupun golongan agama.mengatasi dalam arti memberikan wahana atas tercapainya harkat dan martabat seluruh warganya.negara memberikan kebebasan untuk merealisasikan seluruh potensinya dalam kehidupan bersama yang bersifat integral.oleh karena itu tujuan Negara dirumuskan untuk melindungi segenap warganya dan seluruh tumpah darahnya, memajukan kesejahteraan umum mencerdaskan kehidupan warganya serta dalam kaitanya dengan pergaulan dengan bangsabangsa lain di dunia untuk mewujudkan suatu ketertiban dunia yang berdasarkan perdamaian abadi dn keadilan social.kebinekaan yang kita miliki harus dijaga sebaik mungkin,kebhinekaan yang berdiri tegak di atas moral dan etika bangsa kita sesuai 
dengan keragaman budaya kita sendiri.untuk menjaga kebhinekaan yang bermartabat itulah,maka berbagai hal yang mengancam kebhinekaan mest di tolak, pada saat yang sama segala sesuatu yang mengancam moral kebinekaan mesti diberantas.karena kebinekaan yang bermartabat di atas moral bangsa yang kuat pastilah menjunjung eksistensi dan martabat manusia berbeda. 2. Pengaruh Budaya Luar terhadap Budaya Indonesia. Kebudayaan Indonesia walau beraneka ragam, namun pada dasarnya terbentuk dan dipengaruhi oleh kebudayaan besar lainnya seperti kebudayaan Tionghoa, kebudayaan India dan Kebudayaan Arab. Kebudayaan India masuk dari penyebaran agama Hindu dan Budha di Nusantara jauh sebelum Indonesia terbentuk.dari waktu ke waktu budaya barat semakin marak dan diserap dengan mudah oleh masyarakat kita. Tidak peduli budaya itu merusak ataukah tidak, namun nampaknya masyarakat kita lebih suka menghadapi budaya-budaya luar itu daripada melestarikan budaya tanah airnya sendiri. Hal ini harus bisa disikapi dengan seksama karena bila

kebiasaan ini terus berlangsung tanpa proses penyaringan dan pengontrolan, maka dapat dipastikan bahwa budaya Indonesia akan hilang lenyap tinggal nama. Permasalahan ini timbul bukan karena faktor luar, namun timbul dari diri pribadi masing-masing warga masyarakat yang seakan malu dan menganggap kuno budayanya sendiri. Beberapa contoh budaya asing yang sangat negatif namun telah marak di Indonesia yaitu freesex, pengkonsomsian narkoba, dan abortus. Freesex ini bukan hanya dilakukan oleh orang dewasa saja, namun dari golongan remajalah yang sekarang ini marak diberikan misalnya saja kasus Itenas 1). Pengkonsomsian narkoba dilakukan orang barat untuk merilekskan pikiran mereka dari berbagai macam kerumitan hidup, untuk menambah stamina, semangat, dan kreatifitas saat bekerja itupun dengan dosis aman bagi mereka. Namun di Indonesia mengkonsumsi narkoba adalah ajang coba-coba dan cara menghilangkan stres tanpa mengetahui kandungan zat berbahaya yang ada di dalamnya. Sehingga tidak jarang kasus kematian, tindak kriminal dan kenakalan remaja yang disebabkan benda haram tersebut. Kasus abortus ini sebenarnya tidak terlalu jauh hubungannya dengan kasus freesex inilah banyak kaum wanita yang hamil di luar nikah dan karena rasa malu kebanyakan para wanita itu melakukan aborsi. Selain dibenci oleh Tuhan, kegiatan ini dapat mencelakai pihak wanita itu sendiri. Namun, selain mempunyai sisi negatif budaya barat juga memnpunyai pengaruh positif pada budaya Indonesia, misalnya dalam bidang IPTEK, pembangunan, dsb, yang tentunya kesemuanya itu tidak terlepas dari pengawasan Pancasila sebagai paradigma kehidupan di Indonesia.

KESIMPULAN DAN SARAN Dalam bermasyarakat tentu saja banyak perbedaan pendapat dan perselisihan,dengan adanya masalah tersebut seharusnya kita bisa lebih terbuka dan membantu dalam menegakkan persatuan dan kesatuan,supaya masyarakat bisa saling menghargai perbedaaan yang ada dalam masyarakat. Walaupun masih banyak perselisihan antar umat agama dan antar suku,ini seharusnya dapat kita gunakan untuk pembelajaran supaya kedepan tidak terjadi perselisihan lagi.sehingga masyarakat dapat sadar akan pentingnya persatuan dan kesatuan,manusia yang baik tidak akan melakukan kesalahan yang pernah dilakukan.semoga rakyat lebih menghargai perbedaan yang ada. 


\section{DAFTAR PUSTAKA}

Oktapiani, R., Yanzi, H., \& Nurmalisa, Y. (2016). Hubungan Tingkat Pemahaman Konsep Persatuan Dan Kesatuan Terhadap Sikap Solidaritas Siswa. Jurnal Kultur Demokrasi, 4(2).

Makna, B. A. Pengertian Persatuan dan Kesatuan Bangsa.

Setiabudhi, I. K. R., Artha, I. G., \& Putra, I. P. R. A. (2018). Urgensi Kewaspadaan Dini dalam Rangka Memperkuat Persatuan dan Kesatuan Bangsa. Jurnal Magister Hukum Udayana (Udayana Master Law Journal), 7(2), 250-266.

Oktapiani, R., Yanzi, H., \& Nurmalisa, Y. (2016). Hubungan Tingkat Pemahaman Konsep Persatuan Dan Kesatuan Terhadap Sikap Solidaritas Siswa. Jurnal Kultur Demokrasi, 4(2). 